\title{
ANALISIS TINGKAT KESEHATAN PT. BPR BATANG KAPAS
}

\author{
Mira Handayani, Doni marlius \\ Akademi Keuangan dan Perbankan Padang \\ donimarlius@akbpstie.ac.id
}

\begin{abstract}
The purpose of this study is to determine the health level at PT. Credit Bank Rakyat (BPR) Batang Kapas and should be carried out by PT. BPR Cotton Trunk inside minimize the problems that occur. The focus of this research is focused on: Level Analysis Health of PT. BPR Batang Kapas. The results of the study were the Health Level Analysis of PT. Batang Kapas BPR can be seen in several stages stages of health, assessment of the validity of data or files, analysis of $5 C$, and provisions for collateral already started well, but there is no health at PT. BPR Batang Kapas. It is recommended to state the level of health so that the bank is more selective and careful things to analyze the ability of prospective debtors in the level of health of PT. $B P R$ Cotton stems and prioritize the precautionary principle to avoid error in the level of his health.
\end{abstract}

Keywords: Health of PT. BPR Batang Kapas 


\section{PENDAHULUAN}

\section{Latar Belakang Masalah}

Dunia perbankan merupakan salah satu institusi yang sangat berperan dalam bidang perekonomian suatu Negara (khususnya dibidang pembiayaan perekonomian). Perbankan adalah segala sesuatu yang menyangkut tentang bank, mencakup kelembagaan,kegiatan usaha,serta cara dan proses dalam melaksanakan kegiatan usahanya. Bank adalah badan usaha yang menghimpun dana dari masyarakat dalam bentuk simpanan dan menyalurkannya kepada masyarakat dalam bentuk kredit dan atau bentuk-bentuk lainnya dalam rangka meningkatkan taraf hidup rakyat banyak.

\section{Keberadaan BPR sangat} membantu usaha mikro kecil dan menengah karena kegiatan usaha BPR terutama ditujukan untuk melayani usaha-usaha kecil dan masyarakat di pedesaan dan juga untuk memenuhi kebutuhan masyarakat dalam bidang keuangan dengan ketentuan-ketentuan yang lebih mudah dibandingkan dengan bank umum.Semakin berkembangnya kebutuhan masyarakat,tugas BPR tidak hanya ditujukan bagi masyarakat pedesaan saja tetapi juga mencakup pemberian jasa perbankan bagi masyarakat golongan ekonomi lemah di daerah perkotaan (Melayu: 2006).

Bank Perkreditan Rakyat (BPR) yang merupakan bagian dari sistem Perbankan harus sehat dan dapat di percaya oleh masyarakat supaya bisa berkontribusi maksimal dalam menggerakkan perekonomian secara keseluruhan. Perkembangan usaha BPR yang terus menunjukkan kinerja yang positif,didorong oleh tiga faktor utama yaitu kebijakan pemerintah yang memberikan peluang pendirian BPR, deregulasi perbankan yang memperbesar ruang gerak BPR dan besarnya kebutuhan masyarakat terutama di daerah pinggiran kota dan pedesaan terhadap jasa pelayanan perbankan. Kontribusi BPR akan semakin nyata jika BPR dalam kondisi sehat dan kuat.Penilaian kesehatan BPR telah menjadi indikator penting dalam upaya peningkatan kinerja bank.

Kesehatan bank adalah kemampuan suatu bank untuk melakukan kegiatan operasional perbankan secara normal dan mampu memenuhi semua kewajibannya dengan baik dengan cara-cara yang sesuai dengan peraturan perbankan yang berlaku. Dengan kata lain bank yang sehat adalah bank yang dapat menjaga dan memelihara kepercayaan 
masyarakat,menjalankan

fungsi

intermediasi,dapat

membentuk

kelancaran lalu lintas pembayaran

serta dapat mendukung efektifitas

kebijakan moneter. (Suseno dan Petter

Abdullah dalam Bank Indonesia,2004

Tingkat kesehatan keuangan bank adalah hasil penilaian kuantitatif atas berbagai aspek yang berpengaruh terhadap kondisi atau kinerja suatu bank melalui penilaian Kuantitatif dan atau Penilaian Kualitatif terhadap faktor-faktor

Capital,Asset

Quality,Management,Earning,dan

Liquidity yang di singkat

CAMEL.Tingkat kesehatan keuangan bank juga dapat diartikan sebagai kemampuan suatu bank untuk melaksanakan kegiatan operasional perbankan secara normal dan mampu memenuhi suatu kewajiban dengan cara-cara yang sesuai peraturan perbankan yang berlaku.

Berdasarkan Surat Keputusan Direksi Bank Indonesia No.30/12/KEP/DIR dan Surat Edaran Penilaian Kinerja Menurut SEBI No. 6/10/PBU/2004 tentang Tata cara Penilaian Tingkat Kesehatan Bank Indonesia,dengan menggunakan lima kelompok yaitu permodalan,kualitas aktiva

produktif,manajemen,rentabilitas,dan likuiditas atau lebih dikenal dengan sebutan CAMEL dalam mengukur skala operasi dan struktur pemodalannya.

Pada analisis CAMEL kriteria yang ditentukan oleh Bank Indonesia adalah tentang seberapa besar persentase kinerja keuangan yang memenuhi persyaratan bank tersebut untuk dinyatakan sehat,serta tidak membahayakan /merugikan pihakpihak yang berkepentingan.Analisis CAMEL dikuantifikasikan sebagai aspek penilaian yang merupakan perhitungan rasio keuangan.Oleh karena itu rasio keuangan bermanfaat dalam menilai tingkat kesehatan keuangan bank. Semakin besar skala operasi bank yang diukur dengan total asset dan semakin tinggi jumlah modal dari bank tersebut diharapkan kinerja operasinya semakin baik.

Dari uraian tersebut diatas terlihat bahwa metode CAMEL merupakan salah satu faktor untuk mengadakan penelitian mengenai analisis tingkat kesehatan keuangan bank dengan mengunakan data laporan keuangan pada PT. BPR Batang Kapas.Untuk itu dalam penelitian ini penulis mengambil judul "Analisis Tingkat Kesehatan 
Keuangan PT.Bank Perkreditan

Rakyat (BPR) Batang Kapas”.

\section{Rumusan Masalah}

Berdasarkan uraian latar belakang masalah diatas,maka rumusan masalah dalam penelitian ini adalah :"Apakah tingkat kesehatan keuangan dengan metode CAMEL PT.BPR Batang Kapas selama periode tahun 2014-2015 berada dalam kondisi sehat?"

\section{Tujuan Penelitian}

Penelitian ini bertujuan untuk mengetahui tingkat kesehatan PT.BPR Batang Kapas selama periode tahun 20142015 dengan metode CAMEL.

\section{Manfaat Penelitian}

Adapun manfaat penelitian ini,penulis berharap dapat bermanfaat antara lain:

a. Bagi perusahaan sebagai tolok ukur bagi manajemen BPR Batang Kapas untuk menilai apakah pengelolaan bank sudah dilaksanakan denngan baik sesuai dengan peraturan yang telah ditetapkan dan sebagai acuan untuk menentukan strategi usaha dan kebijakan dimasa akan datang.

b. Bagi penulis untuk memenuhi salah satu syarat untuk mencapai gelar Diploma III Keuangan dan Perbankan di AKBP Padang. c. Sebagai referensi bagi penelitian sejenis

\section{Metode Penelitian}

Di dalam penelitian ini penulis menggunakan metode pengumpulan data dengan dua cara yaitu :

a. Studi Pustaka (Library Research)

Penelitian ini dilakukan dengan cara mempelajari buku-buku,makalahmakalah,artikel-artikel, bacaan laporan-laporan dan publikasi yang berhubungan dengan objek penelitian.

b. Studi Lapangan (Field Research) Penelitian yang langsung dilakukan pada PT.Bank Perkreditan Rakyat Batang Kapas untuk memperoleh data yang diperlukan dan melakukan wawancara untuk mendapatkan data primer.

\section{LANDASAN TEORI}

\section{Sejarah Berdirinya}

Dalam rangka mendorong laju pertumbuhan ekonomi, maka peranan sektor perbankan menjadi salah satu motor penggerak yang cukup penting. Namun keberadaan lembaga perbankan yang telah ada, sejauh ini dianggap belum dapat menyentuh lapisan masyarakat perdesaan.

Menyikapi arti penting sebuah bank dalam mendukung pertumbuhan ekonomi masyarakat desa, Bank Nagari Kabupaten Pesisir Selatan bersama PRO 
MB-GTZ, mendirikan beberapa buah BPR yang ditujukan untuk membantu masyarakat kecil, salah satunya PT. BPR Batang Kapas, yang merupakan kelanjutan kerja dari PRO MB-GT tersebut.

PT. BPR Batang Kapas diresmikan bersama tujuh buah BPR lainnya oleh Gubernur Sumatera Barat yaitu Bapak Zainal Bakar, SH yang dilaksanakan di PT. BPR Batipuh Padang Panjang, sedangkan peresmian di PT. BPR Batang Kapas dilaksanakan pada tanggal 19 Februari 2001 secara simbolis oleh wakil bupati, Bapak Nasrul Abit dan mulai beroperasi pada tanggal 22 Januari 2001.

Akte pendrian PT. BPR Batang Kapas yaitu Akta Notaris Syamsuhardi, SH di Padang No. 155 tanggal 15 Desember 2000 dengan pengesahan oleh Mentri Kehakiman dan Hak Azasi Manusia Republik Indonesia Nomor : C.2985 HT.01.01.TH.2001 dan perubahannya Akta Notaris Syamsuhardi, SH di Padang No. 20 tanggal 11 Agustus 2008 dengan pengesahan oleh Mentri Hukum dan Hak Azasi Manusia Republik Indonesia Nomor : AHU-71440.AH.01.02. Tahun 2008.

PT. BPR Batang Kapas, sebagai Lembaga Keuangan Mikro yang dapat menghimpun dana masyarakat dan memberikan pinjaman modal kerja maupun kebutuhan pinjaman konsumtif bagi masyarakat. Visi PT. BPR Batang Kapas adalah "Tumbuh dan berkembang secara wajar dan sehat dengan home base yang solid". Misi PT. BPR Batang Kapas adalah membantu meningkatkan pertumbuhan ekonomi dan taraf hidup masyarakat.

PT. BPR Batang Kapas bergerak dalam usaha perbankan, melayani Tabungan, Deposito dan Kredit. Pelayanan yang baik menjadi prioritas utama dari BPR ini dengan maksud agar setiap nasabah merasa menjadi bagian dari keluarga besar BPR Batang Kapas .

PT. BPR Batang Kapas sangat peduli dan mendukung setiap program pemerintah dalam hal ini Bank Indonesia dalam mensosialisasikan manfaat menabung dan wawasan akan dunia perbankan itu sendiri khususnya BPR. Maka dari itu, senantiasa mengadakan pendekatan langsung ke masyarakat lewat berbagai penyuluhan dan kegiatan yang bermuatan edukasi perbankan, khususnya pada calon nasabah usia pelajar dan dunia usaha mikro, kecil dan menengah. Dampak nyata dari usaha itu sangat positif dalam membangun citra BPR dimatamasyarakat; para pelajar, pedagang pasar, pemilik warung, pegawai negeri maupun swasta dan para wirausahawan mulai bergabung menjadi nasabah. 


\section{Struktur Organisasi}

Struktur organisasi merupakan hal yang sangat penting untuk dipertmbangkan dalam sebuah organisasi, karena berperan dalam mencapai tujuan perusahaan. Didalam struktur organisasi terlihat jelas pembagian wewenang, tugas dan tanggung jawab personil dalam perusahaan. Adapun pengertian organisasi menurut Siagian (2000:20) ialah setiap bentuk persekutuan antara dua orang atau lebih yang bekerja sama untuk mencapai suatu ikatan hirarki dimana selalu terdapat hubungan antara seseorang atau kelompok orang yang disebut pimpinan dan seseorang atau sekelompok orang yang disebut bawahan.

Dalam suatu organisasi yang sehat, tiap bagian haruslah menjalani fungsinya dengan disiplin dan teratur. Efisiensi yang tercipta karena hubungan yang timbal balik ini akan memberikan perbandingan yang baik antara kerja yang dilakukan dengan hasil yang dicapai. Pengertian struktur organisasi menurut Handoko (2001:54) adalah organisasi dengan segala aktifitasnya, terdapat hubungan antara orang-orang yang menjalankan aktifitas tersebut. Makin banyak kegiatan yang dilakukan dalam suatu organisasi, makin komplek juga hubungan-hubungan yang ada. Untuk itu perlulah dibuat suatu bagan yang menggambarkan tentang hubungan tersebut termasuk hubungan antara masing-masing kegiatan atau fungsi.
Bagan yang dimaksud dinamakan bagan organisasi atau struktur organisasi.

Jadi struktur organisasi pada suatu perusahaan merupakan faktor yang menentukan kegiatan perusahaan terutama dalam melaksanakan tugas yang dibebankan, pendelegasian kekuasaan dalam perusahaan dan pengaturanpengaturan hubungan antara anggota yang terlibat dalam organisasi atau perusahaan dalam usaha mencapai tujuan yang telah ditetapkan. Besar kecilnya struktur organisasi perusahaan ditentukan perusahaan dengan kata lain semakin besar perusahaan maka akan semakin komplek, begitu sebaliknya.

Untuk mengetahui batas dan tanggung jawab yang harus dipikul oleh masing-masing anggota organisasi tersebut, menurut Flippo (2001:107) dapat dilihat dari tipe-tipe organisasi yang dianut oleh perusahaan tersebut :

1. Organisasi garis

Disini setiap bawahan hanya mendapat perintah atau pengawan dari seorang atasan, sehingga yang dikerjakan oleh bawahan menjadi jelas. Dalam hal ini masing-masing orang mempertanggung-jawabkan pekerjaannya hanya pada satu orang atasan.

2. Organisasi fungsional

Dalam organisasi fungsional ini, masalah pembagian pekerjaan sangat 
diperhatikan dan bawahan menjadi pedoman yang dipertahankan dengan segala tanggung jawab, sebab itu atasan dispesialisasikan untuk melakukan suatu tugas dalam kegiatan perusahaan. Dalam hal ini atasan hanya dapat memberikan perintah pada bawahannya sesuai dengan fungsinya, namun setiap atasan dapat memerintahkan setiap pegawai yang berkedudukan lebih rendah darinya

3. Organisasi garis dan staf

Dalam organisasi garis dan staf, yang memberikan perintah hanyalah pimpinan saja sedangkan staf hanya sebagai pembantu pimpinan dalam hal tugas perencanaan. Tipe organisasi ini umumnya terdapat pada perusahaan besar dan punya karyawan banyak serta adanya spesialisasi yang beraneka ragam. Pada tipe ini, pimpinan mengadakan pendelegasian wewenang kepada staf menurut bidangnya masingmasing. Para staf tidak diharuskan menyampaikan usul perintah kepada bawahan, sehingga terjaminlah suatu disiplin kerja karena terhindarnya kesimpangsiuran perintah yang diterima bawahan.

Struktur organisasi PT BPR Batang Kapas yaitu:

1. Pemegang Saham

Tugas pemegang saham adalah membahas kinerja perusahaan dan membentuk dewan-dewan untuk mengatur operasional perusahaan tersebut.

2. Dewan Pengawas

Dewan pengawas merupakan anggota pemegang saham yang mengawasi jalannya perusahaan. Dewan pengawas sebagai pemegang kekuasaan tertinggi yang mengadakan pengawasan dan rapat komisaris bila diperlukan.

3. Direktur Utama

Direktur utama mempunyai tugas sebagai berikut :

a. Membuat rencana kerja PT BPR Batang Kapas.

b. Membuat dan menyampaikan laporan neraca bulanan dan daftar laba/rugi kepada dewan pengawas.

c. Menyetujui atau menolak permohonan kredit yang telah diproses bagian pemberian kredit.

d. Melakukan pendekatan dengan instansi pemerintah, tokoh masyarakat, dan lain-lain.

e. Mengikuti rapat - rapat yang diadakan dikecamatan maupun kabupaten.

f. Mengadakan rapat dengan dewan pengawas dua bulan sekali.

\section{Direktur}

Direktur mempunyai tugas sebagai berikut:

a. Memeriksa transaksi unit kerja

b. Mengatasi dan mengontrol kegiatan operasional setiap kali kegiatan 
c. Mengatur pengeluaran kas untuk keperluan kantor.

d. Memeriksa laporan kerja, seperti : rencana laporan laba/rugi, dan transaksi- transaksi setiap hari.

e. Dua kali seminggu mengadakan pemeriksaan tentang keadaan kas yang dilakukan bersama-sama teller.

f. Mencek tunggakan kredit dibagian administrasi.

5. Satuan pengawas intern.

Tugas satuan pengawas intern adalah sebagai berikut:

a. Mengadakan pengawasan terhadap pelaksanaan tata kerja anggaran belanja dan angagaran pendapatan bank .

b. Memeriksa serta mencocokan kebenaran transaksi yang terjadi pada setiap unit kerja.

c. Memberikan laporan hasil pemeriksaan yang diperoleh kepada Direktur.

6. Bagian Operasional bertugas menghimpun dana dari masyarakat dalam bentuk tabungan dan deposito serta melakukan kegiatan administrasinya. Didalam melaksanakan tugasnya, Bagian Operasional dibantu dan membawahi bagian umum, kasir, pembukuan, bagian umum.

7. Bagian Kredit bertugas memberikan pelayanan kepada masyarakat mengenai kredit serta serta melakukan penagihan dan pengawasan kredit yang telah disalurkan.bagian kredit dibantu dan membawahi administrasi kredit, account officer, dan collector.

\section{Bagian Dana}

Tugas bagian dana adalah sebagai berikut:

a. Melakukan pendekatan dan pembinaan hubungan dengan masyarakat luas, lembaga/instansi, pemerintah/swasta, dan sekolahsekolah dalam rangka promosi, pemasaran produk-produk bank.

b. Melakukan penarikan dan kegiatan antar jemput dari bank ke deposan serta memotivasi calon penabung untuk menempatkan dan mempertahankan nominal dananya dibank.

c. Membuat dan memberikan laporan secara periodik menyangkut mutasi tabungan dan deposito hasil penarikan dilapangan.

\section{Customer Service}

Tugas Cusrtomer Service adalah sebagai berikut :

a. Memberikan pelayanan informasi kepada nasabah, berkaitan dengan permohonan pembukaan rekening tabungan, deposito dan kredit serta memberi pelayanan kepada relasi bank lainnya. 
b. Membuat daftar mutasi harian tabungan, deposito dan cicilan pinjaman yang diberikan dan pendapatan bunga.

c. Memberikan pelayanan untuk pembukuan rekening tabungan, deposito dan registrasinya dalam buku C.I.B serta memberikan pelayanan untuk penukaran/penggatian buku tabungan yang telah penuh, hilang/rusak dan penutupan rekening sesuai ketentuan yang berlaku.

d. Melakukan pendebetan atas rekening tabungan deposito untuk keperluan angsuran/pelunasan kewajiban debitur dan hal lainnya sesuai ketentuan yang berlaku.

e. Menerima dan meneruskan surat/dokumen yang masuk atau keluar dari bank kealamat yang dituju, termasuk suratsurat/dokumen intern perusahaan.

f. Membuat laporan secara berkala:

1) Deposito yang akan jatuh tempo

2) Laporan penerimaan tabungan, deposito, realisasi penerimaan angsuran kredit berikut penerimaan bunganya.

g. Menata berkas-berkas/dokumen yang berkaitan dengan bidang jasa nasabah

10. Kasir

Tugas kasir sebagai berikut : a. Membuka/ menutup khasanah dan brankas.

b. Melayani, mencatat transaksi kas dan meneruskan bukti transaksi kepada bidang accounting secara bertahap untuk setiap hari kerja bersangkutan.

c. Mengajukan permohonan penambahan/pengurangan kas kepada Direktur Utama apabila terjadi kekurangan/kelebihan kas sesuai dengan batas wewenang yang diberikan.

d. Memberikan informasi kas menjelang jam tutup kas kepada Direktur Utama serta membuat mutasi kas pada hari yang bersangkutan.

e. Mensortir dan mengklasifikasikan pecahan mata uang tersebut dan mencocokanya dengan daftar posisi kas yang dibuat pada hari yang bersangkutan.

f. Membuat berita acara apabila terjadi selisih kas sesuai dengan batas yang ditentukan dan melaporkannya kepada Direktur Utama.

g. Mengembalikan sisa kas kedalam brankas setelah jam tutup kas pada hari yang bersangkutan.

\section{Pembukuan}

Tugas pembukuan sebagai berikut: 
a. Memberikan informasi kepada pimpinan atau transaksi termuat yang dibukukan dalam neraca.

b. Memeriksa, menyusun dan membukukan kedalam buku jurnal, buku besar, daftra laba/rugi, berita acara harian kas.

12. Bagian Umum

Tugas bagian umum sebagai berikut:

a. Membuat, mengagendakan, mengarsipkan surat-surat atau dokumen perusahaan lainnya, kecuali yang berkaitan dengan kredit.

b. Membuat daftar atau melaksanakan penyusutan atas harta tetap dan inventaris kantor.

c. Melayani kebutuhan karyawan menyangkut barang-barang cetakan maupun alat tulis dan kebutuhan kerja lainnya, serta memonitor dan mengadministrasikan setiap penambahan dan penguranan serta peminjaman invntaris kantor.

d. Membuat warkat/slip biaya yang berkaitan dengan operasional perusahaan dan nota pemindah buku tabungan, deposito dan kredit.

\section{Account Officer}

Tugas account officer sebagai berikut:

a. Membina hubungan baik dengan masyarakat luas, lembaga/instansi, pemerintah dan swasta serta sekolahsekolah dalam rangka mempromosikan dan memasarkan produk bank.

b. Melakukan kunjungan terhadap calon dan atau debitur serta pihak lainnya, dalam rangka:

1. Observasi usaha masyarakat yang produktif atau potensial untuk dikembangkan dan atau dalam rangka menghimpun dana.

2. Observasi/survey atas kondisi usaha, jaminan kredit dan pengumpulan informasi/datadata sehubungan dengan calon debitur.

3. Melakukan monitor dan pembinaan terhadap usaha debitur, penagihan atas tunggakan kredit serta mempelajari kendala-kendal yang dihadapi debitur dan mengupayakan jalan keluarnya.

c. Melakukan kegiatan wawancara dalam rangka pengumpulan data/informasi langsung dari calon debitur serta mempelajari, meneliti dan menganalisa permohonan kredit, kondisi keuangan usaha dan keabsahan surat-surat yang dilampirkan. 
d. Membuat memorandum/proporsal kredit yang disidangkan serta membacakan keputusan kredit berikut penjelasan pasal-pasal yang dimuat dalam perjanjian hutang dan lampiran-lampirannya terhadap calon debitur.

e. Membuat dan menyampaikan laporan serta secara periodik kepada debitur atas permohonan dan realisasi kredit, hasil penagihan tunggakan kredit, penyelesaian kredit-kredit bermasalah dan hasil penghimpunan tabungan /depsito berjangka.

14. Administrasi Umum

Tugas administrasi umum sebagai berikut:

a. Memeriksa kelengkapan permohonan kredit yang akan disidangkan dan mempersiapkan media-media sesuai dengan persetujuan atau putusan kredit oleh pihak yang berwenang serta melakukan registrasi dan persiapan berkas/dokumen kredit.

b. Mencatat/membukukan setoran debitur kedalam kartu pinjaman, melakukan monitoring atas tata tertib angsuran serta membuat, membalas, mengagendakan dan mengarsip seluruh surat-surat sehubungan dengan kredit. c. Membuat dan menyampaikan daftar - laporan-laporan secara berkala, baik laporan untuk intern perusahaan maupun ekstern perusahaan.

\section{Ruang Lingkup Usaha dan kegiatan usaha \\ Ruang lingkup usaha PT. BPR} Batang Kapas meliputi:

a. Menghimpun dana dari masyarakat dalam bentuk tabungan dan deposito berjangka.

b. Membantu para pengusaha kecil dan menengah dalam bentuk pembiayaan untuk kredit modal kerja, investasi, dan lain-lain.

Kegiatan usaha PT. BPR Batang Kapas meliputi:

1) Menghimpun dana masyarakat dalam bentuk :

a) Tabungan Kami (TAMI) yaitu produk tabungan untuk seluruh lapisan masyarakat mulai dari penabung kecil sampai dengan penabung besar yang dilayani dikantor dan dijemput kepasarpasar, kerumah-rumah dengan sepeda motor (Tabungan Bajapuik).

b) Tabungan Puro Nagari yaitu produk tabungan untuk seluruh lapisan masyarakat , dengan adanya undian-undian yang diadakan oleh BPR-BPR yang 
tergabung dalam Asosiasi bBank Perkreditan Rakyat.

c) Deposito berjangka ditunjukan bagi masyarakat yang menyimpan dana Rp. $\quad 1.000 .000$ keatas dengan jangka waktu minimal 1(satu) bulan.

2) Produk Kredit

a) Kredit Usaha Kami (KUMI)untuk keperluan modal kerja, investasi, dan pembelian barang modal.

b) Kredit Usaha Kecil Informal (KUKI) untuk modal kerja dan investasi dengan angsuran bulanan dalam jangka waktu lima tahun.

c) Kredit Cicilan Uang kepada guruguru dan PNS yang gajinya dibayarkan melalui PT.BPR Batang Kapas.

d) Kredit Pengolahan Usaha Pertanian, Perkebunan, dan Peternakan(KPUP3)

\section{ANALISA DAN PEMBAHASAN}

\section{Analisis Tingkat Kesehatan}

\section{Keuangan PT BPR Batang Kapas}

\section{Tahun 2014-2015}

\section{a. Analisis terhadap Faktor \\ Permodalan (Capital)}

Untuk mengukur tingkat kesehatan keuangan bank dapat diketahui dari analisa rasio kecukupan modal. Rasio ini digunakan untuk mengukur sejauh mana penurunan yang terjadi dalam total aktiva yang bisa ditutupi oleh modal yang tersedia.

Penilaian terhadap pemodalan PT.BPR Batang Kapas menggunakan rasio CAR yang merupakan perbandingan antara modal dengan aktiva tertimbang menurut resiko. Dapat diketahui pada tabel dibawah ini

Tabel 3.3

CAR PT BPR Batang Kapas tahun 2014-2015

\begin{tabular}{|c|c|c|c|c|}
\hline \multirow{2}{*}{$\begin{array}{c}\text { Keterang } \\
\text { an }\end{array}$} & \multicolumn{2}{|l|}{2014} & \multicolumn{2}{|r|}{2015} \\
\hline & Jumlah (Rp) & $\begin{array}{l}\text { Penin } \\
\text { gkata } \\
\mathrm{n}(\%)\end{array}$ & $\begin{array}{l}\text { Jumlah } \\
\text { (Rp) }\end{array}$ & Peningkatan $(\%)$ \\
\hline $\begin{array}{l}\text { a. Jumlah } \\
\text { modal }\end{array}$ & 4.797 .895 .319 & - & $\begin{array}{r}5.782 .5 \\
65.870\end{array}$ & $20,52 \%$ \\
\hline $\begin{array}{l}\text { b. } \\
\text { Jumlah } \\
\text { ATMR }\end{array}$ & 1.915 .292 .274 & - & $\begin{array}{r}2.113 .6 \\
29.009\end{array}$ & $10,35 \%$ \\
\hline $\begin{array}{l}\mathrm{CAR}= \\
\mathrm{a} / \mathrm{b} \times 100 \\
\%\end{array}$ & \multicolumn{2}{|l|}{$25,05 \%$} & \multicolumn{2}{|r|}{$27,35 \%$} \\
\hline
\end{tabular}

Sumber : Data Olahan

Perhitungan nilai kredit $(\mathrm{NK})$ rasio

CAR

$$
\begin{aligned}
& N K=\frac{\text { Rasio }}{0,1 \%}+1 \\
& N K 2014=\frac{25,05 \%}{0,1 \%}+1=251,5 \\
& N K 2015=\frac{27,35 \%}{0,1 \%}+1=274,5
\end{aligned}
$$


Dari tabel 3.3 diatas dapat dilihat bahwa resiko kecukupan modal (CAR) mengalami peningkatan ada tahun 2014 sebesar $2,3 \%$ dikarenakan terjadinya peningkatan modal sebesar $20,52 \%$ lebih besar dari pada peningkatan ATMR $10,35 \%$ sedangkan untuk CAR tahun 2014-2015 lebih besar dari 8\% berarti dikatakan SEHAT dalam menyediakan pemodalannya untuk menghadapi resikoresiko yang mungkin timbul .

Untuk nilai kredit BPR CAR Batang Kapas pada tahun 2014 adalah sebesar 251,5 dan tahun 2015 adalah sebesar 274,5. Karena nilai kredit dibatasi maksimum 100 maka nilai rasio CAR BPR Batang Kapas tahun 2014-2015 diakui sebesar 100 .

\section{b. Assets Quality (Kualitas Aktiva Produktif)}

Penilaian didasarkan kepada kualitas aktiva yang dimiliki Bank. Rasio yang diukur ada 2 macam yaitu :

a. Rasio KAP (Rasio Aktiva Produktif Yang Diklasifikasikan /APYD terhadap Aktiva Produktif)

APYD menggambarkan Aktiva Produktif yang kurang lancar, diragukan atau macet. Semakin besar APYD tersebut maka semakin besar kondisi aktiva produktif yang potensial untuk tidak dapat ditagih atau macet. Dari hasil perhitungan, APYD BPR Batang Kapas dari tahun 2014-2015 semakin kecil. APYD pada tahun 2014 sebesar Rp 142.007.342 dan ditahun 2015 sebesar Rp 122.499.974. Hal ini mengindikasikan bahwa kualitas aktiva produktif BPR Batang Kapas semakin meningkat. Berikut ini perhitungan Kualitas Aktiva Produktif (KAP) pada BPR Batang Kapas tahun 2014-2015.

Tabel 3.4

Laporan Kolektibilitas Aktiva Produktif

PT.BPR Batang Kapas Tahun 2014

\begin{tabular}{|c|c|c|}
\hline Komponen & Nominal & Bobot (\%) \\
\hline A. Aktiva & & \\
\hline Produktif yg & & \\
\hline Diklasifikasikan & & $0 \%$ \\
\hline (APYD) & 6.390 .111 .0 & $50 \%$ \\
\hline - Lancar & 88 & $75 \%$ \\
\hline Kurang Lancar & 9.555 .668 & $100 \%$ \\
\hline Diragukan & 19.253 .337 & \\
\hline Macet & 122.789 .50 & \\
\hline Jumlah APYD & 6 & \\
\hline B. Aktiva & & \\
\hline Produktif & 17.459.793. & \\
\hline - Kredit yg & 230 & \\
\hline Diberikan & 3.125 .439 .2 & \\
\hline - Penempatan pd & 33 & \\
\hline Bank Lain & & \\
\hline Jumlah Aktiva & & \\
\hline Produktif & & \\
\hline
\end{tabular}

Sumber: Data Olahan 
Tabel 3.5

Laporan Kolektibilitas Aktiva Produktif

PT. BPR Batang Kapas Tahun 2015
$N K 2014=\frac{22,5 \%-0,68 \%}{0,15 \%}=145($ maksimum 100$)$

$N K 2015=\frac{22,5 \%-0,53 \%}{0,15 \%}=146($ maksimum 100$)$

Rasio KAP BPR Batang Kapas

\begin{tabular}{|c|c|}
\hline Komponen & Nominal \\
\hline \multicolumn{2}{|l|}{ A. Aktiva Produktif yg } \\
\hline \multicolumn{2}{|l|}{ Diklasifikasikan (APYD) } \\
\hline - Lancar & 6.845 .247 .033 \\
\hline - Kurang Lancar & 4.175 .300 \\
\hline · Diragukan & 8.647 .788 \\
\hline - Macet & 113.926 .483 \\
\hline \multicolumn{2}{|l|}{ Jumlah APYD } \\
\hline Komponen & Nominal \\
\hline \multicolumn{2}{|l|}{ B. Aktiva Produktif } \\
\hline - Kredit yg Diberikan & 19.426 .565 .476 \\
\hline . Penempatan pd Bank & 3.616 .789 .820 \\
\hline Lain & \\
\hline Jumlah Aktiva & \\
\hline Produktif & \\
\hline
\end{tabular}

Sumber: Data Olahan

Perhitungan Rasio KAP PT. BPR

Batang Kapas adalah sebagai berikut:

Bobot (\%)
pada tahun 2014 adaliah sebesar $0,68 \%$ diklasifikasikan mengalami penurunan ditahun 2015 menjadi $0,53 \%$. Semakin kecilnya rasio KAP disebabkan karena jumlah APYD yazpg semakin kecil dalam 0 artian bahwa dspi\%tahun ke tahun.085Batang Kapas señp baik dalam mesig8tholla pemberian kreffinya. Selain itu dis jumlah Aktiva prbelukfly.97ang dari tahun

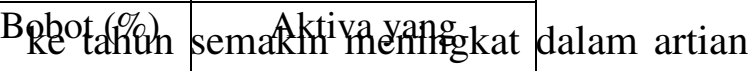
bahwa jumlah diklasifikasikan disalurkan BPR Batang Kapas dari tahun ke tahun semakin besar.

BPR Batang Kapas selama periode 2014-2015 mampu menjaga rasio KAP dibawah 10,35\% 20.043 .353 .298 berdasarkan kriteria penilaian rasio KAP BPR Batang Kapas dapat dikategorikan dalam kelompok SEHAT. Kecilnya rasio KAP yang diperoleh BPR Batang Kapas menunjukkan bahwa BPR memiliki aktiva

$K A P=\frac{\text { Jumlah Aktiva Produktif yan Diklasifpikodruktiafn }}{\text { Jumlah Aktiva Produktif bermasalah yang relatif kecil. Karena }} \times 100 \%$ semakin kecil rasio KAP, maka semakin KAP $2014=\frac{142.007 .342}{20.585 .232 .468} \times 100 \%=0,68 \%$ besar tingkat kemungkinan diterimanya KAP $2015=\frac{122.499 .974}{23.043 .355 .296} \times 100 \%=0,53 \%$ kembali dana yang ditanamkan.

Perhitungan nilai kredit (NK) rasio KAP :
Berdasarkan perhitungan nilai kredit KAP pada tahun 2014 adalah sebesar 145 dan pada tahun 2015 sebesar 
146. Maka nilai rasio KAP BPR Batang Kapas tahun 2014-2015 dapat diakui sebesar 100, karena untuk nilai kredit dibatasi maksimum 100.

b. Rasio PPAP (Rasio Penyisihan Penghapusan Aktiva Produktif terhadap Penyisihan Penghapusan Aktiva Produktif Yang Wajib Dibentuk (PPAPYD).

PPAPYD merupakan penyisihan penghapusan aktiva produktif yang dibentuk guna menutup risiko kemungkinan kerugian. Semakin besar PPAP maka modal bank akan semakin kecil karena besarnya PPAP ini dicadangkan dari modal. Berikut ini adalah hasil perhitungan rasio PPAP pada BPR Batang Kapas tahun 2014-2015:

Tabel 3.6

Laporan Kolektibilitas Aktiva Produktif PT.BPR Batang Kapas Tahun 2014

\begin{tabular}{|c|c|c|c|c|}
\hline \multicolumn{2}{|c|}{ Komponen } & Nominal & $\begin{array}{l}\text { Bo } \\
\text { bot } \\
(\%)\end{array}$ & $\begin{array}{c}\text { Aktiva } \\
\text { yang } \\
\text { diklasifika } \\
\text { sikan } \\
\text { (rupiah) }\end{array}$ \\
\hline \multicolumn{2}{|c|}{ PPAP } & & & 127.823 .2 \\
\hline \multicolumn{5}{|c|}{ PPAPWD } \\
\hline- & Lancar & 6.390 .11 & 0,5 & 319.505 .5 \\
\hline \multicolumn{2}{|c|}{ - Kuran } & 1.088 & $\%$ & 54 \\
\hline & $\mathrm{g}$ & 9.555 .66 & 10 & 955.566 \\
\hline & lancar & 8 & $\%$ & 9.626 .688 \\
\hline \multirow[t]{2}{*}{ - } & Diragu & 19.253 .3 & 50 & 122.789 .5 \\
\hline & kan & 37 & $\%$ & 06 \\
\hline- & Macet & 122.789 & 100 & 452.877.2 \\
\hline
\end{tabular}

\begin{tabular}{|l|l|l|l|}
\hline $\begin{array}{l}\text { Jumlah } \\
\text { PPAPWD }\end{array}$ & 506 & $\%$ & $\mathbf{9 4}$ \\
& & & \\
\hline
\end{tabular}

Sumber: Data Olahan

Tabel 3.7

Laporan Kolektibilitas Aktiva Produktif

PT.BPR Batang Kapas Tahun 2015

\begin{tabular}{|c|r|r|r|}
\hline Komponen & Nominal & $\begin{array}{r}\text { Bo } \\
\text { bot } \\
(\%)\end{array}$ & \multicolumn{1}{c|}{$\begin{array}{c}\text { Aktiva } \\
\text { yang } \\
\text { diklasifik } \\
\text { asikan } \\
\text { (rupiah) }\end{array}$} \\
\hline PPAP & & & $\mathbf{1 1 2 . 2 5 3 . 7}$ \\
& & & $\mathbf{7 9}$ \\
\hline PPAPWD & & & \\
Lanca & 6.845 .24 & 0,5 & 342.262 .3 \\
r & 7.033 & $\%$ & 51 \\
Kuran & 4.175 .30 & 10 & 417.530 \\
g & 0 & $\%$ & 4.323 .894 \\
lancar & 8.647 .78 & 50 & 113.926 .4 \\
- Dirag & 8 & $\%$ & 83 \\
ukan & 113.926. & 100 & $\mathbf{4 6 0 . 9 3 0 . 2}$ \\
- Macet & 483 & $\%$ & $\mathbf{5 8}$ \\
Jumlah & & & \\
PPAPWD & & & \\
\hline
\end{tabular}

Sumber: Data Diolah

Perhitungan Rasio PPAP

RASIO PPAP $=\frac{P P A P}{P P A P W D} \times 100 \%$

PPAP 2014 $=\frac{127.823 .228}{452.877 .294} \times 100 \%=28 \%$

$P P A P 2015=\frac{112.253 .779}{460.930 .258} \times 100 \%=24 \%$

Perhitungan nilai kredit (NK)

PPAP 
NK $2014=\frac{28 \%}{1 \%}=28$

NK $2015=\frac{24 \%}{1 \%}=24$

BPR Batang Kapas selama periode 2014-2015 tidak mampu menjaga rasio PPAP sebesar $81 \%$ sehingga berdasarkan kriteria penilaian rasio PPAP BPR Batang Kapas dapat dikategorikan dalam kelompok TIDAK SEHAT. Hal ini mengindikasikan bahwa BPR Batang Kapas tidak mampu menjaga kolektabilitas atau pinjaman yang disalurkan semakin baik.

Berdasarkan hasil perhitungan, nilai kredit PPAP BPR Batang Kapas pada tahun 2014 sebesar 28 lalu ditahun 2015 adalah sebesar 24. Karena nilai kredit dibatasi maksimum 100 maka nilai rasio PPAP BPR Batang Kapas pada tahun 2014-2015 tidak diakui sebagai 100.

\section{c. Khusus untuk aspek manajemen tidak dapat dijelaskan karena keterbatasan data dan keterbatasan penulis .}

\section{d. Analisis terhadap faktor Earnings}

\section{(Rentabilitas)}

Dalam penghitungan rentabilitas digunakan dua rasio yaitu Return on Asset(ROA) dan Rasio Biaya Operasional terhadap Pendapatan Operasional (BOPO). ROA adalah perbandingan laba sebelum pajak dengan rata-rata total aktiva, sementara BOPO adalah perbandingan pendapatan operasional. Perhitungannya dapat dilihat dari tabel dibawah ini :

Tabel 3.8

Perhitungan Faktor Rentabilitas PT. BPR

Batang Kapas

tahun 2014-2015

\begin{tabular}{|l|r|r|}
\hline \multicolumn{1}{|c|}{$\begin{array}{c}\text { Kompone } \\
\mathrm{n}\end{array}$} & \multicolumn{2}{|c|}{ Tahun } \\
\cline { 2 - 3 } $\begin{array}{l}\text { Laba } \\
\text { Sebelum } \\
\text { Pajak }\end{array}$ & 478.744 .705 & 545.285 .280 \\
\hline $\begin{array}{l}\text { Total } \\
\text { Aktiva }\end{array}$ & 21.845 .491 .6 & 24.383 .506 .2 \\
\hline $\begin{array}{l}\text { Beban } \\
\text { Operasion } \\
\text { al }\end{array}$ & 3.336 .314 .91 & 3.575 .070 .91 \\
\hline $\begin{array}{l}\text { Pendapata } \\
\mathrm{n}\end{array}$ & 6 & 8 \\
Operasion & & \\
al & & \\
\hline
\end{tabular}

Sumber : PT. BPR Batang Kapas

1.Perhitungan Rasio ROA

$$
R O A=\frac{\text { Laba Sebelum Pajak }}{\text { Total Aktiva }} \times 100 \%
$$

$$
R O A 2014=\frac{478.744 .705}{21.845 .491 .637} \times 100 \%=2,1 \%
$$

ROA $2015=\frac{545.285 .280}{24.383 .506 .204} \times 100 \%=2,2 \%$

Perhitungan nilai kredit (NK) ROA

$N K 2014=\frac{2,1 \%}{0,015 \%}=140($ maksimum 100$)$ 
NK $2015=\frac{2,2 \%}{0,015 \%}=146($ maksimum 100)

Berdasarkan hasil perhitungan diatas, BPR Batang Kapas mampu menjaga ROA tetap berada diatas $1,215 \%$ sehingga berdasarkan kriteria penilaian ROA BPR Batang Kapas dapat dikategorikan dalam kelompok SEHAT. Dengan tingginya rasio ROA ini menunjukkan bahwa BPR Batang Kapas mampu dengan baik dalam mengelola asset bank yang dimiliki untuk menghasilkan laba.

Untuk nilai kredit ROA BPR Batang Kapas pada tahun 2014 sebesar 140 dan pada tahun 2015 sebesar 146 , hal ini dapat diakui sebesar 100. Karena batasan maksimum nilai kredit adalah 100 .

2. Perhitungan rasio BOPO $B O P O=\frac{\text { Beban Operasional }}{\text { Pendapatan Operasional }} \times 100 \%$

BOPO $2014=\frac{3.336 .314 .916}{3.820 .802 .620} \times 100 \%=87 \%$

BOPO $2015=\frac{3.575 .070 .918}{4.127 .157 .198} \times 100 \%=86 \%$

Perhitungan Nilai kredit (NK)

BOPO
$N K 2015=\frac{100 \%-86 \%}{0,08 \%}=175($ maksimum 1

BOPO BPR Batang Kapas pada tahun 2014 adalah sebesar 87\% dan ditahun 2015 sebesar 86\%. Berdasarkan hasil perhitungan tersebut, BPR Batang Kapas mampu menjaga BOPO tetap berada dibawah $93,52 \%$ sehingga berdasarkan kriteria penilaian BOPO BPR Batang Kapas dapat dikategorikan dalam kelompok SEHAT. Dengan semakin kecilnya rasio BOPO maka semakin efisien BPR Batang Kapas dalam melakukan kegiatan operasionalnya karena biaya yang dikeluarkan lebih kecil dibandingkan pendapatan yang diterima.

Untuk nilai kredit BOPO BPR Batang Kapas pada tahun 2015 sebesar 162 dan pada tahun 2012 sebesar 175 , hal ini dapat diakui sebesar 100. Karena batasan maksimum nilai kredit adalah 100 .

\subsubsection{Analisis terhadap Faktor}

\section{Likuiditas (Liquidity)}

Likuiditas adalah kemampuan untuk membayar kewajiban finansial jangka pendek tepat pada waktunya yang ditunjukkan oleh besar kecilnya aktiva lancar. Penilaian likuiditas dimaksudkan untuk mengevaluasi kemampuan Bank memelihara tingkat likuiditas yang NK $2014=\frac{100 \%-87 \%}{0,08 \%}=162($ maksimum 100$)$ dan kecukupan manajemen 
resiko likuiditas. Penilaian dalam unsur ini yaitu didasarkan pada dua rasio yaitu:

a. Cash Ratio (CR): perbandingan antara aktiva likuid terhadap hutang lancar.

b. Loan to Deposit Ratio (LDR): perbandingan antara kredit terhadapdana yang diterima bank.

\section{Tabel 3.9}

Perhitungan Faktor Likuiditas PT. BPR Batang Kapas

Tahun 2014-2015

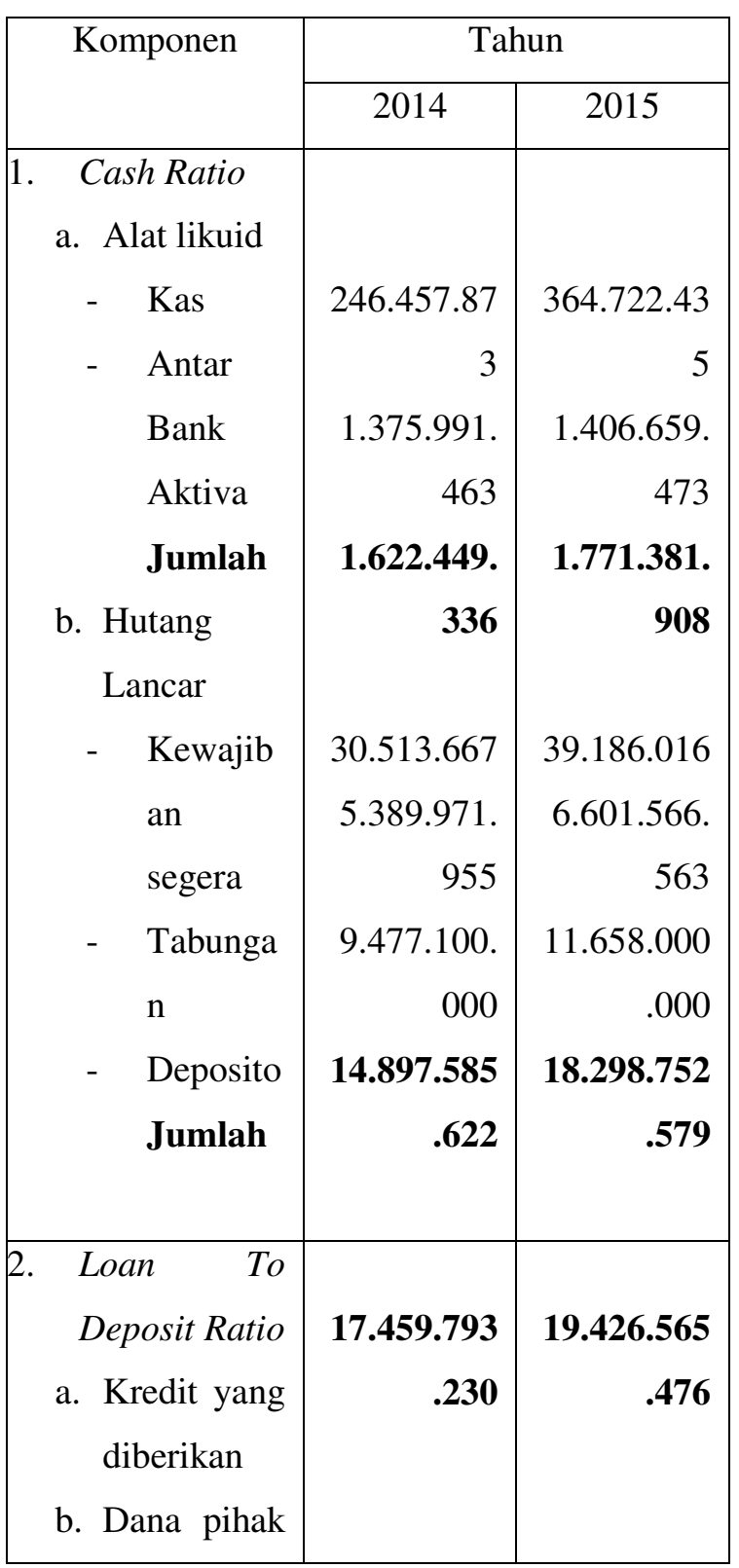

\begin{tabular}{|l|r|r|}
\hline ketiga dan & 5.389 .971$. & 6.601 .566$. \\
Modal & 955 & 563 \\
- Tabunga & 9.477 .100$. & 11.658 .000 \\
$\mathrm{n}$ & 000 & .000 \\
- Deposito & 2.101 .380$. & 2.601 .500$. \\
- Modal & 000 & 000 \\
Jumlah & $\mathbf{1 6 . 9 6 8 . 4 5 1}$ & $\mathbf{2 0 . 8 6 1 . 0 6 6}$ \\
& $\mathbf{. 9 5 5}$ & $\mathbf{. 5 6 3}$ \\
& & \\
& &
\end{tabular}

Sumber: Data diolah

a. Perhitungan $\mathrm{CR}$

$$
\begin{aligned}
& C R=\frac{\text { Alat likuid }}{\text { Hutang Lancar }} \times 100 \% \\
& \text { CR } 2014=\frac{1.622 .449 .336}{14.897 .585 .622} \times 100 \%=11 \% \\
& \text { CR } 2015=\frac{2.771 .381 .908}{18.298 .752 .579} \times 100 \%=15 \% \\
& \text { Perhitungan nilai kredit }(\mathrm{NK}) \mathrm{CR} \\
& \text { NK }=\frac{\text { Angka rasio }}{0,05 \%} \times 1 \\
& \text { NK 2014 }=\frac{11 \%}{0,05 \%} \times 1=220 \\
& \text { NK 2015 }=\frac{15 \%}{0,05 \%} \times 1=300 \\
& \text { Ratio BPR Batang Kapas }
\end{aligned}
$$
pada tahun 2014 sebesar $11 \%$ dan tahun 2015 sebesar 15\% Berdasarkan hasil perhitungan tersebut, BPR Batang Kapas mampu menjaga Cash Ratio tetap berada 
diatas 4,05\% sehingga berdasarkan kriteria penilaian Cash Ratio BPR Batang Kapas dapat dikategorikan dalam kelompok

\section{SEHAT.}

Untuk nilai kredit CR BPR Batang Kapas tahun 2014 sebesar 220 dan tahun 2015 sebesar 300 maka dapat diakui sebagai 100. Karena nilai kredit dibatasi maksimum 100.

b. Perhitungan rasio LDR

kriteria penilaian LDR BPR Batang Kapas dapat dikategorikan dalam kelompok SEHAT.

\section{PENUTUP}

\section{Kesimpulan}

Berdasarkan hasil analisis pada bab sebelumnya bahwa penelitian yang berjudul "ANALISIS TINGKAT KESEHATAN KEUANGAN PT.BANK PERKREDITAN RAKYAT (BPR) $L D R=\frac{\text { Kredit yang diberikan }}{\text { Dana pihak ketiga }+ \text { modal }} \times \begin{gathered}\text { BATANG } \\ 100 \% \\ \text { kesimpulan sebagai berikut: }\end{gathered}$ KAPAS” dapat ditarik

1. Gambaran tingkat kesehatan bank PT. LDR 2014 $=\frac{17.459 .793 .230}{16.968 .451 .955} \times 100 \%=\begin{array}{r}\mathrm{BPR} \text { Batang Kapas menunjukan kinerja } \\ \text { yang sehat } / \text { baik. Hal ini ditunjukkan }\end{array}$ dengan indikator sebagai berikut :

LDR $2015=\frac{19.426 .565 .476}{20.861 .066 .563} \times 100 \%=93 \%$ Permodalan $(\mathrm{CAR})$ pada PT. BPR Batang Kapas untuk periode 2014Perhitungan nilai kredit (NK) LDR 2015 dalam kategori sehat. Rasio permodalan yang diperoleh PT. BPR $N K=\frac{115 \%-\text { Angka rasio }}{1 \%} \times 4$ Batang Kapas selama tahun 20142015 adalah sebesar 25,05\% (2014),

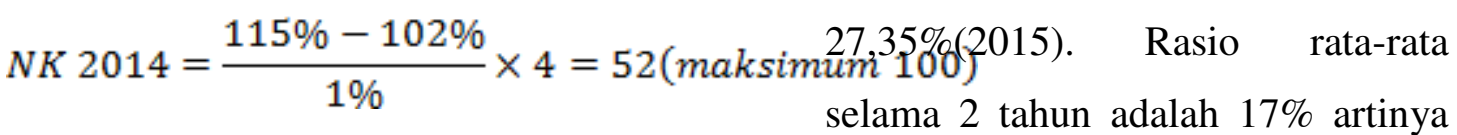
NK $2015=\frac{115 \%-93 \%}{1 \%} \times 4=88($ maksimumasio $)$ di atas ketentuan yang ditetapkan Bank Indonesia.

LDR BPR Batang Kapas pada tahun 2014 sebesar $102 \%$ dan tahun 2015 sebesar $93 \%$ Berdasarkan hasil perhitungan tersebut, BPR Batang Kapas mampu menjaga LDR tetap berada dibawah $94,75 \%$ sehingga berdasarkan b. KAP yang dimiliki PT. BPR Batang Kapas untuk periode 2014-2015 sebesar 0,68\%(2014), 0,53\%(2015). Rasio PPAP yang diperoleh PT. BPR Batang Kapas selama tahun 20142015 adalah sebesar 28\%(2014) ,24\%(2015) dinyatakan Tidak Sehat, 
dengan hasil analisa yang menunjukkan bahwa dalam kurung waktu 2 tahun terakhir aktiva produksi yang termasuk dalam kategori kredit macet mengalami penurunan.

c. Rentabilitas yang didasarkan pada ROA dan PT. BPR Batang Kapas dikategorikan sehat dengan rasio ROA.Sedangkan untuk rasio BOPO dalam 2 periode tergolong sehat, karena telah memenuhi kriteria sebagai bank yang sehat dengan rasio kurang dari 93,52\%, dimana PT. BPR Batang Kapas juga berhasil meningkatkan pendapatannya.

d. Likuiditas yang didasarkan pada cash ratio dalam dua tahun terakhir tergolong sehat, hal ini ditunjukkan dengan rasio yang dihasilkan semakin meningkat yaitu dari $11 \%$ (2014), 15\% (2015) .Sedangkan untuk rasio LDR periode 2014-2015 adalah sebesar 102\% (2014), 93\% (2015).

2. Berdasarkan analisa tingkat kesehatan PT. BPR Batang Kapas, telah memenuhi standard tingkat kesehatan bank yang ditetapkan oleh Bank Indonesia berdasarkan metode CAMEL.

\section{Saran}

1. Meskipun penilaian tingkat kesehatan pada PT. BPR Batang Kapas mendapat predikat sehat, tetapi ada beberapa hal yang perlu mendapat perhatian dari pihak bank yang bersangkutan untuk mengadakan perbaikan agar mampu mempertahankan bahkan meningkatkan tingkat kesehatan bank tersebut.

2. Adapun saran yang dapat penulis sampaikan adalah :

a. Ada baiknya jika pihak bank berusaha untuk semakin meningkatkan aspek permodalan, karena modal merupakan salah satu faktor penting bagi bank dalam rangka mengembangkan usaha dan menampung resiko kerugian. Sebagai perusahaan daerah, penambahan permodalan dapat dilakukan dengan menambah anggaran untuk modal perusahaan tersebut. Semakin tinggi modal yang dimiliki bank akan semakin mempertinggi CAR. CAR yang lebih tinggi membuat bank semakin kuat karena kemampuannya yang lebih tinggi dalam menanggung resiko kerugian. Selain itu tingginya CAR berpengaruh untuk menumbuhkan 
kepercayaan masyarakat terhadap bank tersebut.

b. Untuk memperbaiki kualitas aktiva produktif ada baiknya jika PT. BPR Batang Kapas mempertahankan atau meningkatkan jumlah PPAP yang dibentuk sehingga dapat menutup resiko yang mungkin timbul apabila perputaran aktiva produktif kurang lancar dan sejalan dengan upaya mengurangi jumlah kredit yang bermasalah terutama yang dikategorikan kredit macet.

\section{DAFTAR PUSTAKA}

Bank Indonesia.199 . UU No tahun1998

\section{,Tentangperubahanterhadap}

$\boldsymbol{U} \boldsymbol{U}$

No 7 Tahun 1992, Jakarta.

Bank Indonesia. 1997. SuratEdaean BI No. 30/3/UPPB Tanggal 30 April 1997 Tentang Tata Cara Penilaian Tingkat Kesehatan Bank Perkreditan Rakyat. Jakarta: Bank Indonesia.

Dendawijaya,Lukman. 2000.

ManajemenPerbankan. Jakarta :Ghalia Indonesia.

Flippo,Edwin

B. 2001.
Kuncoro,MudarajaddanSuhardjono. 2002. ManajemenPerbankan,TeoridanAp likasi.Yogyakarta : BPFE.

Riyanto,Bambang.2010.

ManajemenKeuangan. Yogyakarta : BPFE.

Sinungan,Murcdasyah. 2010. Manajemen

Dana Bank. Jakarta : PT. BumiAksara.

Sutojo,Siswanto.2009.

ManajemenTerapan . Jakarta :Pustaka Pressindo.

Totok Budi Santoso\& Tri Handaru,2006.

Bank danLembagaKeuangan

Lain.SalembaEmpat. Jakarta.

Undang-UndangPerbankan No. 101998 TentangPerbankan. 2000. Jakarta Sinargrafika.

\section{ManajemenPersonalia.Jakarta :Erlangga}

